\title{
Hydrolysis of pineapple crown biomass by cellulolytic enzymes produced by Fusarium oxysporum
}

\author{
Hidrólise da biomassa da coroa do abacaxi por enzimas celulolíticas produzidas por \\ Fusarium oxysporum
}

\author{
I. L. dos Santos*; G. G. Amaral; A. C. M. Lima; L. T. A. de Bastos; A. C. \\ Santos; F. C. Paula-Elias; C. C. A. A. Santos; A. F. de Almeida \\ Postgraduate Program in Food Science and Technology - Laboratory of Applied Microbiology, Federal \\ University of Tocantins, 77001-090, Palma-TO, Brazil. \\ *iara.sant23@gmail.com \\ (Trabalho avaliado e selecionado pela Comissão do III CTOCTA)
}

\begin{abstract}
The development of microbial enzymes is of great importance in biochemical process industries. Among the enzymes of industrial importance, cellulolytic and xylanolytic enzymes stand out, which are responsible for the degradation of lignocellulosic material that is usually discarded by the agro-industrial sector. In order to produce the enzymes CMCase, $\beta$-glycosidase, xylanase and $\beta$-xylosidase, the fungus Fusarium oxysporum was used in liquid fermentation using pre-treated pineapple crown biomass as a carbon source. In order to optimize the production of these enzymes, cultures were carried out for 168 hours, $30^{\circ} \mathrm{C}$ at 180 $\mathrm{rpm}$. The biomass underwent a pre-treatment in two stages, the first being submitted to $121^{\circ} \mathrm{C}$ for $7 \mathrm{~min}$, while the second was added diluted sulfuric acid to $1 \%$, in the proportion of $1: 5(\mathrm{~m} / \mathrm{v})$, at $121^{\circ} \mathrm{C}$ for 27 minutes. The partial characterization of the crude extract showed a temperature of $50{ }^{\circ} \mathrm{C}$ as the most satisfactory for the action of these enzymes, and the ideal $\mathrm{pH}$ range ranged from 3.5 to 5.5 . The enzymatic hydrolysis of pineapple crown, with and without pretreatment, was performed using lyophilized crude extract $(\mathrm{CMCase}=9.78 \mathrm{U} / \mathrm{mL}, \beta$-glucosidase $=10.86 \mathrm{U} / \mathrm{mL}$, xylanase $=27.90 \mathrm{U} / \mathrm{mL}$ and $\beta$-xylosidase $=$ $0.018 \mathrm{U} / \mathrm{ml}$ ). An experimental design of the Central Composite Rotational Design was carried out. It was possible to evaluate the effect and influence of $\mathrm{pH}$, biomass concentration and incubation time on the release of glucose in the medium $\left(\mathrm{R}^{2}>0.85\right) ; \mathrm{pH}$ and biomass $(\%)$ had a significant effect on glucose release.

Keywords: Ananas comosus, celullolytics enzymes, experimental planning.
\end{abstract}

O desenvolvimento de enzimas de origem microbiana é de grande importância nas indústrias de processos bioquímicos. Dentre as enzimas de importância industrial, destacam-se as enzimas celulolíticas e xilanolíticas grandes responsáveis pela degradação do material lignocelulósico que costuma ser descartado pelo setor agroindustrial. Com objetivo de produção das enzimas CMCase, $\beta$-glicosidase, xilanase e $\beta$ xilosidase, foi utilizado o fungo Fusarium oxysporum em fermentação líquida usando biomassa pré-tratada de coroa de abacaxi como fonte de carbono. Visando otimizar a produção dessas enzimas os cultivos foram realizados por 168 horas, $30^{\circ} \mathrm{C}$ a $180 \mathrm{rpm}$. A biomassa passou por um pré-tratamento em duas etapas, sendo a primeira submetida à $121^{\circ} \mathrm{C}$ por 7 minutos, já à segunda foi acrescentado ácido sulfúrico diluído a $1 \%$, na proporção de $1: 5(\mathrm{~m} / \mathrm{v})$, a $121{ }^{\circ} \mathrm{C}$ por $27 \mathrm{~min}$. A caracterização parcial do extrato bruto apontou temperatura de $50^{\circ} \mathrm{C}$ como a mais satisfatória para ação dessas enzimas, e a faixa de $\mathrm{pH}$ ideal variou de 3.5 a 5.5. As hidrólises enzimáticas de coroa de abacaxi com e sem pré-tratamento, foram realizadas usando extrato bruto liofilizado $(\mathrm{CMCase}=9,78 \mathrm{U} / \mathrm{mL}, \beta$-glicosidase $=10,86 \mathrm{U} / \mathrm{mL}$, xilanase $=27,90 \mathrm{U} / \mathrm{mL}$ e $\beta$ xilosidase $=0,018 \mathrm{U} / \mathrm{mL}$ ). Para tal, foi realizado um planejamento experimental de Delineamento Composto Central Rotacional (DCCR). O qual foi possível avaliar o efeito e influência do $\mathrm{pH}$, da concentração de biomassa e tempo de incubação na liberação de glicose no meio $\left(\mathrm{R}^{2}>0,85\right)$; o pH e a biomassa (\%) apresentaram efeito significativo sobre a liberação de glicose.

Palavras-chave: Ananas comosus, enzimas celulolíticas, planejamento experimental.

\section{INTRODUCTION}

The use of agro-industrial residues is a trend in the development of research aimed at the production of biofuels and enzymes of commercial interest. These residues basically consist of lignocellulosic biomass, which favors the growth of microorganisms that produce 
lignocellulolytic enzymes [1,2]. Currently, these enzymes represent about $20 \%$ of commercially available enzymes [3].

Pineapple residue is rich in simple sugars and carbohydrates, such as cellulose and hemicellulose, which can be hydrolyzed into fermentable sugars. However, it is necessary that the residue is pre-treated and saccharified before fermentation [4].

The pre-treatment aims to prevent the loss of these carbohydrates, prevent the formation of fermentation inhibiting agents and facilitate the formation of fermentable sugars by hydrolysis reactions. In addition to the elimination of lignin, which has an affinity to form bonds with lignocellulolytic enzymes, causing an inhibitory effect [5, 6].

Enzymes are a safe and effective alternative for agro-industrial waste management. The efficiency of the enzymatic action depends on several factors such as temperature, extraction time, $\mathrm{pH}$ conditions and substrate availability $[7,8]$.

Microbial cellulases are mainly obtained by filamentous fungi, such as Trichoderma reesei and Aspergillus niger. In the search for new microorganisms, Fusarium oxysporum, which has the ability to degrade cellulose, has been studied for its high rate of production of endoglycosidases $[9,10]$.

Fusarium oxysporum is one of the few microbial species with recognized ability to carry out saccharification under aerobic conditions and fermentation under anaerobic conditions. [11]. In addition to the high production of endoglycosidase, $F$. oxysporum is also capable of producing $\beta$ glucosity with sufficient activity to prevent a drastic inhibition by excess cellobiose, which directly affects enzymatic hydrolysis [12].

Thus, this work aimed to evaluate the potential of cellulolytic and hemicellulolytic enzymes produced by $F$. oxysporum under submerged conditions to hydrolyze the pineapple crown for the release of glucose.

\section{MATERIALS AND METHODS}

The experiments were carried out at the Laboratory of Biotechnology/Analysis of Food and Product Purification (LABAP), Federal University of Tocantins, Gurupi, Tocantins, Brazil. Fusarium oxysporum strain was isolated from decaying pequi fruits [13], preserved by the Castellani method [14]. The reactivation of the strain was carried out in PDA medium (agardextrose-potato) for 5 days at $28{ }^{\circ} \mathrm{C}$.

\subsection{Submerged cultivation}

Cultivations of $F$. oxysporum were carried out in $125 \mathrm{~mL}$ Erlenmeyer flasks containing $20 \mathrm{~mL}$ of culture medium with the composition: $\mathrm{H}_{2} \mathrm{PO}_{4} 2.0 \mathrm{~g} / \mathrm{L}$, $\left(\mathrm{NH}_{4}\right) 0.4 \mathrm{~g} / \mathrm{L}$, urea $0.3 \mathrm{~g} / \mathrm{L}$, $\mathrm{MgSO}_{4}+7 \mathrm{H}_{2} \mathrm{O} 0.3 \mathrm{~g} / \mathrm{L}, \mathrm{CaCl}_{2} 0.3 \mathrm{~g} / \mathrm{L}, \mathrm{FeSO}_{4}+7 \mathrm{H}_{2} \mathrm{O} 5.0 \mathrm{mg} / \mathrm{L}, \mathrm{MnSO}_{4}+\mathrm{H}_{2} \mathrm{O} 1.56 \mathrm{mg} / \mathrm{L}$, $\mathrm{ZnSO}_{4}+7 \mathrm{H}_{2} \mathrm{O} 1.4 \mathrm{mg} / \mathrm{L}, \mathrm{CoCl}_{2} 2.0 \mathrm{mg} / \mathrm{L}$, meat peptone $0.75 \mathrm{mg} / \mathrm{L}$, yeast extract $0.25 \mathrm{~g} / \mathrm{L}$ and Tween $800.2 \mathrm{mg} / \mathrm{L}$. The culture medium was supplemented with $1 \%$ pretreated or fresh pineapple crown as a carbon source. The medium was sterilized in an autoclave at $121{ }^{\circ} \mathrm{C}$ for $20 \mathrm{~min}$. The cultures were inoculated with $1 \mathrm{~mL}$ of spore suspension at a concentration of $10^{6}$ spores per $\mathrm{mL}$ at $30{ }^{\circ} \mathrm{C}$ under constant agitation of $180 \mathrm{rpm}$ for 120 hours. Samples were taken every 24 hours up to 240 hours to determine the best cultivation time for enzyme production.

\subsection{Enzymatic cellulase activities}

To determine the optimum $\mathrm{pH}$ of the enzymes produced by $F$. oxysporum different $\mathrm{pH}$ ranges were used using glycine-sodium hydroxide buffer ( $\mathrm{pH} 8$ to 13) and McIlvaine buffer ( $\mathrm{pH} 2.0$ to 8.0 ). 


\subsubsection{CMCase activity}

The determination of endoglucanase enzymatic activity was performed using CMC $1 \%(\mathrm{w} / \mathrm{v})$ solubilized in McIlvaine pH 5.0 buffer as reaction medium. In test tubes, $400 \mu \mathrm{l}$ of this medium was added. The tubes were kept at $50{ }^{\circ} \mathrm{C}$ for $5 \mathrm{~min}$. Tubes were prepared with $200 \mu \mathrm{L}$ of DNS reagent, composed of double sodium potassium tartrate tetrahydrate, sodium hydroxide and 3,5dinitrosalicylic acid [15]. Experiments were taken in duplicate at $540 \mathrm{~nm}$. A unit is defined as the amount of enzyme that releases $1 \mu \mathrm{mol}$ of glucose per milliliter per minute of reaction.

\subsection{2 $\beta$-glycosidase activity}

Enzyme activity was performed using 1\% (w/v) salicin solution in McIlvaine $\mathrm{pH} 5.0$ buffer as reaction medium. In test tubes, $400 \mu \mathrm{L}$ of this medium were added, the tubes were kept at $37^{\circ} \mathrm{C}$ for 5 minutes. Tubes were prepared with $200 \mu \mathrm{L}$ of DNS reagent, composed of double sodium and potassium tartrate tetrahydrate, sodium hydroxide and 3,5-dinitrosalicylic acid [15]. Experiments were taken in duplicate at an absorbance of $540 \mathrm{~nm}$. A unit is defined as the amount of enzyme that releases $1 \mu \mathrm{mol}$ of glucose per milliliter per minute of reaction.

\subsubsection{Xylanse activity}

Enzyme activity was performed using $1 \%$ (w/v) xylan in McIlvaine $\mathrm{pH}$ 5.0. In test tubes, 400 $\mu \mathrm{L}$ of the reaction medium were added, which were kept at $50{ }^{\circ} \mathrm{C}$ for 5 minutes. Tubes were prepared with $200 \mu \mathrm{L}$ of DNS reagent, composed of double sodium and potassium tartrate tetrahydrate, sodium hydroxide and 3,5-dinitrosalicylic acid [15]. Experiments were taken in duplicate at an absorbance of $540 \mathrm{~nm}$. A unit is defined as the amount of enzyme that releases 1 $\mu$ mol of xylose per milliliter per minute of reaction.

\subsection{4 $\beta$-xylosidase activity}

$\beta$-xylosidase activity was performed using a $0.25 \%(w / v)$ solution of p-nitrophenyl $\beta$-Dxylopyranoside (pNP-xyl) solubilized in McIlvaine $\mathrm{pH} 5.0$ buffer. In test tubes, $50 \mu \mathrm{L}$ of the reaction medium was placed and then $150 \mu \mathrm{L}$ of McIlvaine $\mathrm{pH} 5.0$ buffer was added. Tubes were prepared with $1 \mathrm{~mL}$ of saturated sodium tetraborate solution. Tubes with reaction medium and buffer were incubated at $50{ }^{\circ} \mathrm{C}$ for 5 minutes. Experiments were taken in duplicate at an absorbance of $410 \mathrm{~nm}$. A unit is defined as the amount of enzyme that releases $1 \mu \mathrm{mol}$ of $\mathrm{p}$ nitrophenol per milliliter per minute of reaction.

\section{ENZYMATIC HYDROLYSIS OF LIGNOCELLULOSIC BIOMASS}

\subsection{Acid pre-treatment of pineapple crown}

Pineapple crown was dried in an oven at $60{ }^{\circ} \mathrm{C}$ for 48 hours. After drying, the biomass was milled in a knife mill in the particle size range between 16 and 60 mesh.

Biomass pretreatment was divided into 2 steps. First a physical pre-treatment at a temperature of $121{ }^{\circ} \mathrm{C}$ for $7 \mathrm{~min}$. Then, a chemical pre-treatment that consisted of adding sulfuric acid $\left(\mathrm{H}_{2} \mathrm{SO}_{4}\right)$ diluted to $1 \%$ to the biomass, in the proportion of $1: 5$ biomass to acid and heating at $121{ }^{\circ} \mathrm{C}$ for 27 minutes according to the methodology of De Araújo et al. (2002) [13].

After pretreatment, the biomass was washed in order to stabilize the $\mathrm{pH}$ to neutrality. This biomass was oven dried at $60{ }^{\circ} \mathrm{C}$ to constant weight. Four repetitions of this process were performed to determine the biomass yield obtained after this pre-treatment. 


\subsubsection{Freeze drying of the gross extract}

The crude extract obtained from the filtration of cultures was frozen at $-20{ }^{\circ} \mathrm{C}$. After this freezing, the crude extract was lyophilized at $-47^{\circ} \mathrm{C}$ under vaccum.

\subsubsection{Enzymatic hydrolysis and hydrolysis analysis}

The hydrolysis reactions were carried out in flasks containing $2 \mathrm{~mL}$ of buffered medium, biomass with and without pre-treatment and lyophilized crude enzymatic extract $(2.5 \mathrm{U} / \mathrm{mL})$. Flasks were incubated with refrigerated orbital shaking at $50{ }^{\circ} \mathrm{C}$ under $180 \mathrm{rpm}$ shaking.

To analyze the hydrolysis of the pineapple crown biomass, the enzymatic colorimetric method of the Glucose Liquiform Labtest ${ }^{\circledR}$ kit was used, and a standard curve was performed with a glucose solution $(0.1-1.0 \mathrm{mg} / \mathrm{mL})$. Samples were taken in a spectrophotometer in the absorbance range of $505 \mathrm{~nm}$, according to the Labtest methodology (2011) [16].

\subsection{Experimental planning}

Enzymatic hydrolysis experiments were carried out with biomass pretreated or without pretreatment with Central Composite Rotational Design (CCRD) with 3 variables: pH, biomass concentration and incubation time, as shown in Table 1 . The program used to carry out the design was STATISTICA Trial®.

Table 1: Actual values of the variables studied in planning the study of $\mathrm{pH}$, biomass and reaction time for biomass with and without pretreatment.

\begin{tabular}{cccccc}
\hline Variables & $\mathbf{- 1 . 6 8}$ & $\mathbf{- 1}$ & $\mathbf{0}$ & $\mathbf{+ 1}$ & $\mathbf{+ 1 . 6 8}$ \\
\hline $\mathbf{p H}$ & 2.48 & 3.5 & 5.0 & 6.5 & 7.52 \\
Biomass (\%) & 1.96 & 4.0 & 7.0 & 10 & 12.04 \\
Time (hours) & 31.7 & 48 & 72 & 96 & 112.3 \\
\hline
\end{tabular}

\section{RESULTS AND DISCUSSION}

\subsection{Pre-treatment of pineapple crown}

After the physical and chemical pre-treatment steps it was obtained $6.37 \mathrm{~g}, 5.63 \mathrm{~g}, 5.88 \mathrm{~g}$ and $6.05 \mathrm{~g}$ of treated biomass. The mean pretreatment yield between repetitions in percentage was $29.6 \%$ (Table 2). The significant drop in weight is justified by the loss of most of the lignin and hemicellulose that was present in the biomass and by the loss of other compounds that were not directly linked to the cellulose [17].

Table 2: Determination of initial and final weight and biomass yield of pineapple crown after heat and acid pre-treatment.

\begin{tabular}{cccc}
\hline Repetition & Initial Weight $(\mathbf{g})$ & Final Weight $(\mathbf{g})$ & Performance $(\boldsymbol{\%})$ \\
\hline $\mathbf{1}$ & 20.0 & 6.3 & 31.5 \\
$\mathbf{2}$ & 20.0 & 5.6 & 28.0 \\
$\mathbf{3}$ & 20.0 & 5.8 & 29.0 \\
$\mathbf{4}$ & 20.0 & 6.0 & 30.0 \\
\hline
\end{tabular}




\subsection{Determination of cultivation time}

The best time for the production of CMCase and $\beta$-glucosidase enzymes was 168 hours, obtaining an activity of $0.90 \mathrm{U} / \mathrm{mL}$ for CMCase and an activity of $1.12 \mathrm{U} / \mathrm{mL}$ for $\beta$-glucosidase, results similar to those found by Santos et al. (2021) [18], when analyzing the production of cellulases by Penicillium sp. FSDE15 reaching maximum production for CMCase $(1.19 \pm 0.06$ $\mathrm{U} / \mathrm{mL}$ ) in cultivation using corn bran in 168 hours. In tests with combination of cob and corn bran, the highest activity $(1.41 \pm 0.05 \mathrm{U} / \mathrm{mL})$ was obtained in 216 hours (Figure 1).

For the xylanase enzyme, the best times were between 144 hours and 240 hours, reaching an activity of $2.50 \mathrm{U} / \mathrm{mL}$. The $\beta$-xylosidase enzyme had the best fermentation time with 192 hours, with an activity of $0.002 \mathrm{U} / \mathrm{mL}$ (Figure 1).

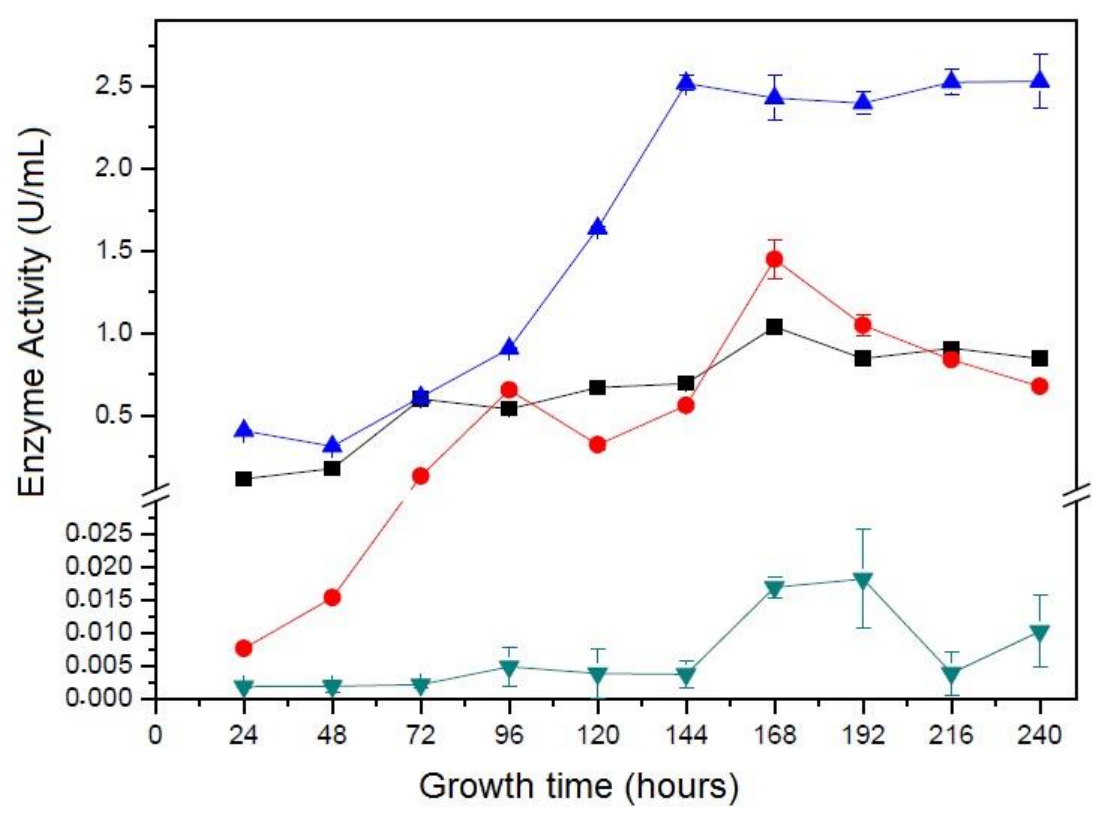

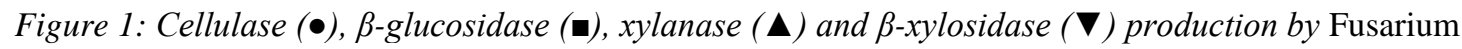
oxysporum in submerged cultures using pretreated pineapple crown.

Different results were reported by Kumar et al. (2017) [19], in their work on xylanase production from Thermomyces lanuginosus VAPS-24, in which the optimal production of the xylanase enzyme occurred within 120 hours. After 144 hours the activity has decreased, this decline in production may be due to nutrient depletion or production of toxic metabolites.

\subsection{Partial characterization of the gross statement}

\subsubsection{Effect of temperature on the activity of cellulolytic enzymes}

The best temperature for the activity of cellulolytic and xylanolytic enzymes produced by $F$. oxysporum was determined by activity tests varying the temperature from 15 to $70{ }^{\circ} \mathrm{C}$. The best temperature of the enzyme CMCase and $\beta$-xylosidase was $50{ }^{\circ} \mathrm{C}$, and for the enzymes $\beta$ glucosidase and xylanase the optimum temperature was 50 to $60^{\circ} \mathrm{C}$ (Figure 2).

$\mathrm{Xu}$ et al. (2016) [20], obtained an optimal temperature for cellulase activity at $45^{\circ} \mathrm{C}$, but when the temperature increased to $55^{\circ} \mathrm{C}$, the enzyme lost more than half of its activity. The recombinant Aspergillus nidulans xylanase had an optimal temperature of $50^{\circ} \mathrm{C}$ [21]. 


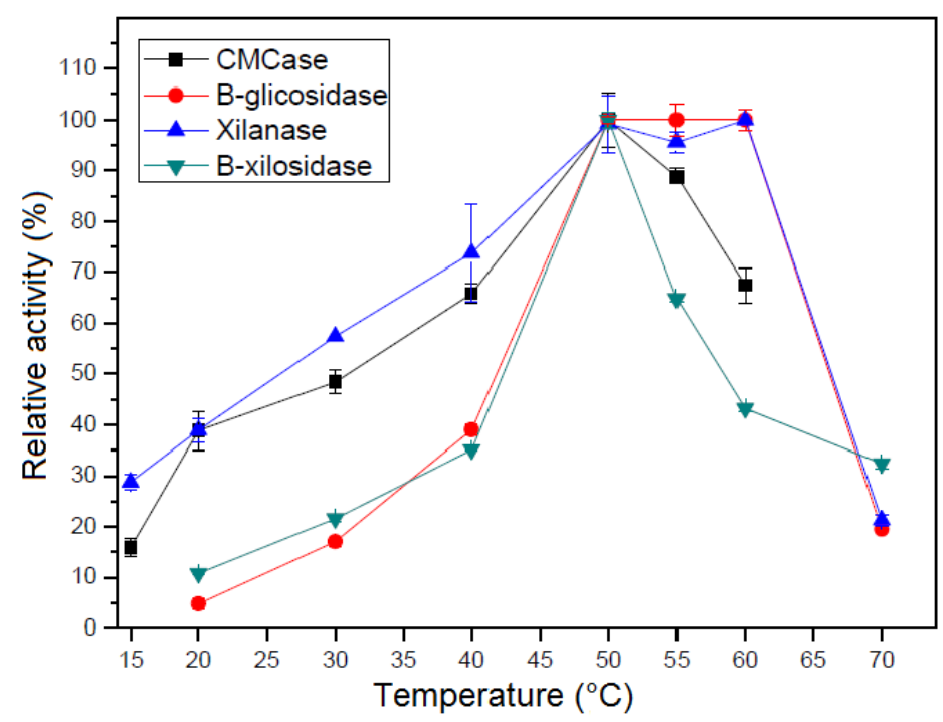

Figure 2: Optimum temperature for enzymatic activity of cellulase, $\beta$-glucosidase, xylanase and $\beta$ xylosidase enzymes produced by Fusarium oxysporum under submerged conditions.

\subsubsection{Effect of pH on cellulolytic enzyme activity}

For CMCase enzyme, the best activity $\mathrm{pH}$ was 3.5 , with an activity of $1.53 \mathrm{U} / \mathrm{mL}$; for $\beta$ glucosidase the best $\mathrm{pH}$ was 5.0 , with an activity of $0.58 \mathrm{U} / \mathrm{mL}$. For xylanolytic enzymes more than one optimum $\mathrm{pH}$ value was obtained; xylanase showed activity peaks at $\mathrm{pH} 4.5,6.5$ and 8.5, respectively with activities of $3.22 \mathrm{U} / \mathrm{mL}, 2.76 \mathrm{U} / \mathrm{mL}$ and $2.88 \mathrm{U} / \mathrm{mL}$; for the $\beta$-xylosidase enzyme, the best $\mathrm{pH}$ range was 4.5 to 5.5 with an average activity of $0.004 \mathrm{U} / \mathrm{mL}$ (Figure 3).

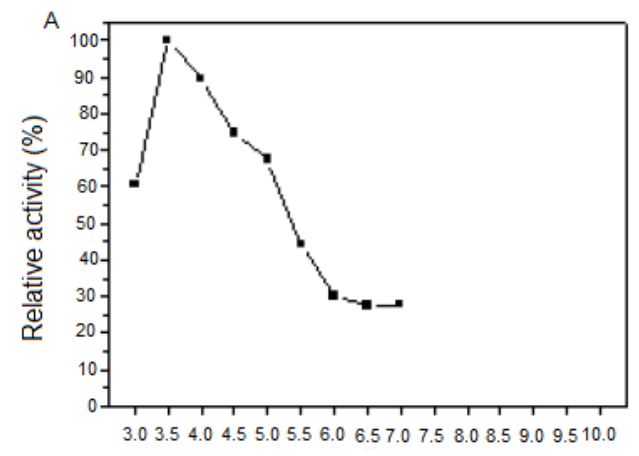

$\mathrm{pH}$

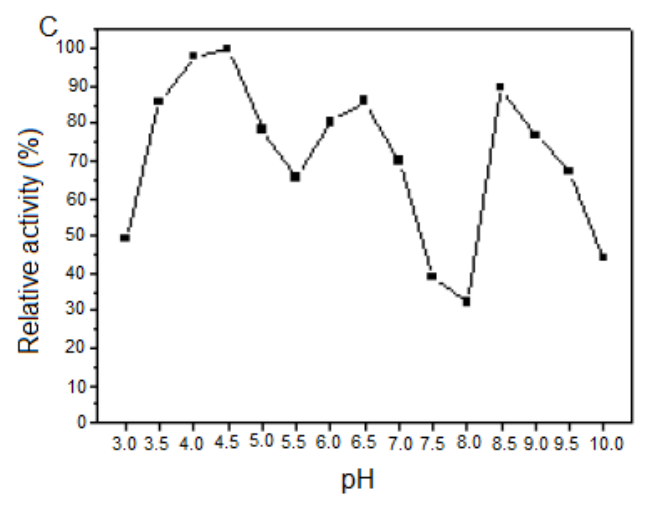

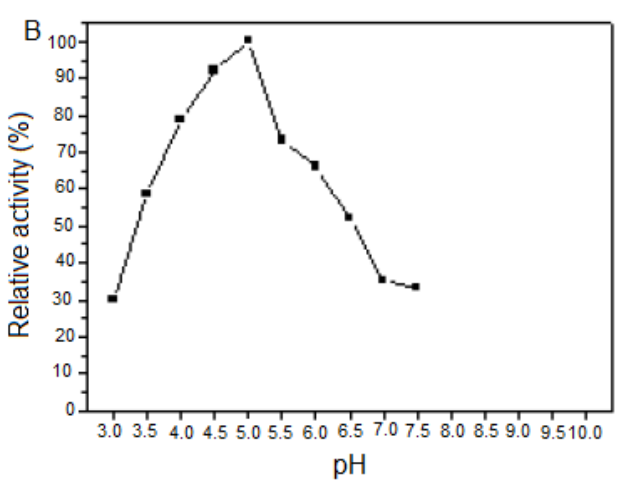

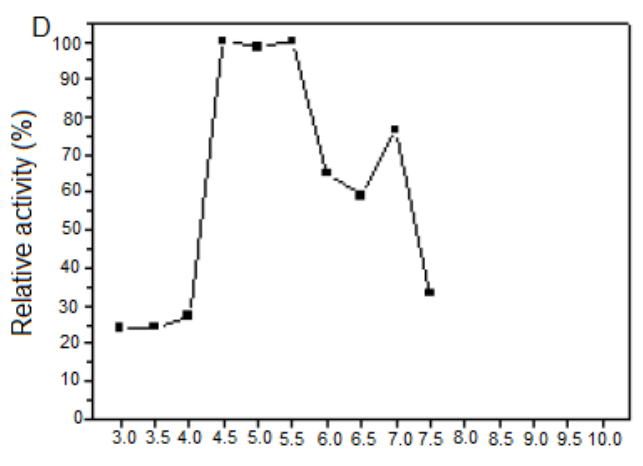

$\mathrm{pH}$

Figure 3: Optimal $p H$ of enzyme activity for CMCase (A), $\beta$-glycosidase (B), xylanase (C) and $\beta$ xylosidase $(D)$ produced by Fusarium oxysporum under submerged conditions. 
The $\mathrm{pH}$ for enzyme activity is mainly related to the isoelectric point of proteins. With the balance of positive and negative charges of the ionic groups, it is concluded that the active sites of the molecule are free to bind to the target molecules (substrates). Therefore, at the $\mathrm{pH}$ where the molecule has a net electrical charge, the greatest formation of the substrate-enzyme complex occurs, with the greatest release of product, maximizing the enzymatic activity.

The CMCase and $\beta$-glucosidase enzymes showed, respectively, an acidic $\mathrm{pH}$ range, the xylanase enzyme showed an optimal $\mathrm{pH}$ for acidic media, neutral and basic, and can be applied to several industrial biochemical processes due to its wide $\mathrm{pH}$ range. The $\beta$-xylosidase enzyme showed greater activity in the $\mathrm{pH}$ range between 4.5 and 5.5.

Singh et al. (2021) [22], when evaluating the production of cellulase and xylanase by Aspergillus flavus using agro-industrial residues as a carbon source, obtained optimal conditions of initial $\mathrm{pH}$ of 5.5 .

\subsection{Hydrolysis}

\subsubsection{Compound central rotational design (DCCR)}

The results of glucose release are shown in Table 3.

Table 3: Values of glucose concentrations released into biomass with pre-treatment $(P T)$ and without treatment (ST) using the DCCR experimental design.

\begin{tabular}{ccc}
\hline Assay & Glucose PT $(\mathbf{m g} / \mathbf{m L})$ & Glucose ST $(\mathbf{m g} / \mathbf{m L})$ \\
\hline 12 & 11.18 & 9.40 \\
5 & 8.40 & 0.01 \\
7 & 14.27 & 0.31 \\
$15(\mathrm{C})$ & 10.06 & 10.15 \\
2 & 0.63 & 1.70 \\
10 & 7.66 & 0.02 \\
$17(\mathrm{C})$ & 10.45 & 9.09 \\
8 & 19.75 & 10.51 \\
4 & 4.48 & 1.93 \\
9 & 0.12 & 0.30 \\
14 & 10.36 & 7.84 \\
$16(\mathrm{C})$ & 10.03 & 10.30 \\
1 & 1.09 & 1.12 \\
11 & 2.70 & 1.33 \\
3 & 1.89 & 3.09 \\
13 & 4.27 & 10.48 \\
6 & 14.63 & 2.00 \\
\hline
\end{tabular}

Experimental conditions: $250 \mu \mathrm{L}$ of lyophilized enzymatic extract, $50^{\circ} \mathrm{C}$ and $180 \mathrm{rpm}$.

The highest values of glucose release for biomass PT occurred in tests 6, 7 and 8; all at pH 6.5 and outside the endpoints for biomass and incubation time. For ST biomass, the best glucose release values were recorded in tests 8,13 and 16. Test 8 at $\mathrm{pH} 6.5$ and the other two at $\mathrm{pH}$ 5.0. Untreated biomass has lignin, which justifies the relatively lower values, as lignin forms irreversible bonds with the enzymes responsible for hydrolysis [23, 24].

The lowest values of glucose release from the PT biomass occurred in tests 1,2 and 9; where 1 and 2 had a pH of 3.5 and test 9 consisted of the minimum pH endpoint, with a value of 2.48. For ST biomass, the lowest values of glucose release were observed in tests 5, 9 and 10; where test 5 had a pH of 6.5 and tests 9 and 10 corresponded to the minimum (2.48) and maximum (7.52) $\mathrm{pH}$ endpoints. 
The use of biomass without any type of treatment is not common in works that aim to release glucose by the hydrolysis process. In the literature, the main lines of research seek to optimize the conditions of hydrolysis, mainly facilitating the access of enzymes to crystalline cellulose.

Saini et al. (2016) [6] showed that the pretreatment steps are important to increase the accessibility of glucose and xylan to hydrolytic enzymes, and the yield of this hydrolysis is related to the type of pretreatment adopted.

\subsubsection{Statistical data analysis}

The estimate of the effect of $\mathrm{pH}$, biomass concentration and time for biomass with pretreatment (PT) is shown in Table 4 and for biomass without treatment (ST) in Table 5.

Table 4: Effects of independent variables on biomass with pretreatment (PT) for glucose release using the DCCR experimental design.

\begin{tabular}{|c|c|c|c|c|c|c|}
\hline Factors & $\mathbf{R}^{2}$ & $\mathbf{R}^{2}$ adj. & Effect & Error & $\mathbf{T}$ & $\mathbf{P}$ \\
\hline (1)pH (L) & & & 9.029 & 1.727 & 5.225 & 0.001 \\
\hline $\mathbf{p H}(\mathbf{Q})$ & & & -2.951 & 1.901 & -1.551 & 0.164 \\
\hline (2)Biomass (L) & & & 4.379 & 1.727 & 2.534 & 0.038 \\
\hline Biomass $(\mathbf{Q})$ & & & -0.798 & 1.901 & -0.419 & 0.687 \\
\hline (3)Time (L) & 0.857 & 0.673 & 3.532 & 1.727 & 2.044 & 0.080 \\
\hline Time (Q) & & & -0.530 & 1.901 & -0.279 & 0.788 \\
\hline $1(\mathrm{~L})$ by $2(\mathrm{~L})$ & & & 1.590 & 2.257 & 0.704 & 0.503 \\
\hline $1(\mathrm{~L})$ by $3(\mathrm{~L})$ & & & 2.393 & 2.257 & 1.060 & 0.324 \\
\hline $2(\mathrm{~L})$ by $3(\mathrm{~L})$ & & & 0.575 & 2.257 & 0.255 & 0.806 \\
\hline
\end{tabular}

Table 5: Effects of independent variables on untreated biomass (ST) for glucose release using the DCCR experimental design.

\begin{tabular}{ccccccc}
\hline Factors & $\mathbf{R}^{\mathbf{2}}$ & $\mathbf{R}^{\mathbf{2}}$ adj. & Effect & Error & $\mathbf{T}$ & $\mathbf{P}$ \\
\hline (1)pH (L) & & & 0.665 & 1.593 & 0.417 & 0.688 \\
pH (Q) & & & $-\mathbf{7 . 5 1 5}$ & $\mathbf{1 . 7 5 3}$ & $\mathbf{- 4 . 2 8 6}$ & $\mathbf{0 . 0 0 3}$ \\
(2) Biomass (L) & & & 3.600 & 1.593 & 2.260 & 0.058 \\
Biomassa (Q) & & & -3.836 & 1.753 & -2.188 & 0.064 \\
(3) Time (L) & 0,807 & 0,560 & 1.050 & 1.593 & 0.659 & 0.530 \\
Time (Q) & & & -1.147 & 1.753 & -0.654 & 0.533 \\
1 (L) by 2 (L) & & & 1.651 & 2.081 & 0.793 & 0.453 \\
1 (L) by 3 (L) & & & 3.189 & 2.081 & 1.532 & 0.169 \\
2 (L) by 3 (L) & & & 1.621 & 2.081 & 0.778 & 0.461 \\
\hline
\end{tabular}

The regression $\mathrm{R}^{2}$ values obtained ( 0.857 for PT biomass and 0.807 for ST biomass) were considered good, indicating that the experimental points fit the model. For the values of $\mathrm{R}^{2}$ adj. of regression ( 0.673 for PT biomass and 0.560 for ST biomass) it is considered that the coefficient of determination of the model does not adequately adjust to the experimental points $[25,26]$.

For biomass PT (Table 3), it can be seen that the linear effect of $\mathrm{pH}$ had a positive response on the release of glucose, in parallel, the linear effect of biomass concentration also had a positive response. For the ST biomass (Table 4), it was observed that only the quadratic effect of $\mathrm{pH}$ showed a significant response, which was negative on hydrolysis. The evaluated effects were significant at the level of $5 \%$ in the induction of glucose release. 


\subsubsection{Reparameterized equation and response surface}

A reparametrized regression model was developed taking into account only the significant variables, to predict the glucose concentration released by hydrolysis as a function of the linear effects of $\mathrm{pH}(\mathrm{LX} 1)$ and biomass concentration (LX2) and the quadratic effect of $\mathrm{pH}(\mathrm{QX} 4)$ for biomass PT (Equation 1) and for biomass ST (Equation 2).

$$
\begin{gathered}
\text { Glucose }\left(\frac{m g}{m L}\right)=9,363+4,514 \times 1+2,189 \times 2 \\
\text { Glucose }\left(\frac{m g}{m L}\right)=9,642-3,757 \times 4
\end{gathered}
$$

Quadratic models act as a three-dimensional function to generate a response surface. Figure 4 represents the response surface for biomass hydrolysis $\mathrm{PT}$ taking into account the $\mathrm{pH}$ and biomass (\%) parameters, Figure 5 represents the response surface for the biomass hydrolysis ST considering the $\mathrm{pH}$ and biomass parameters $(\%)$.

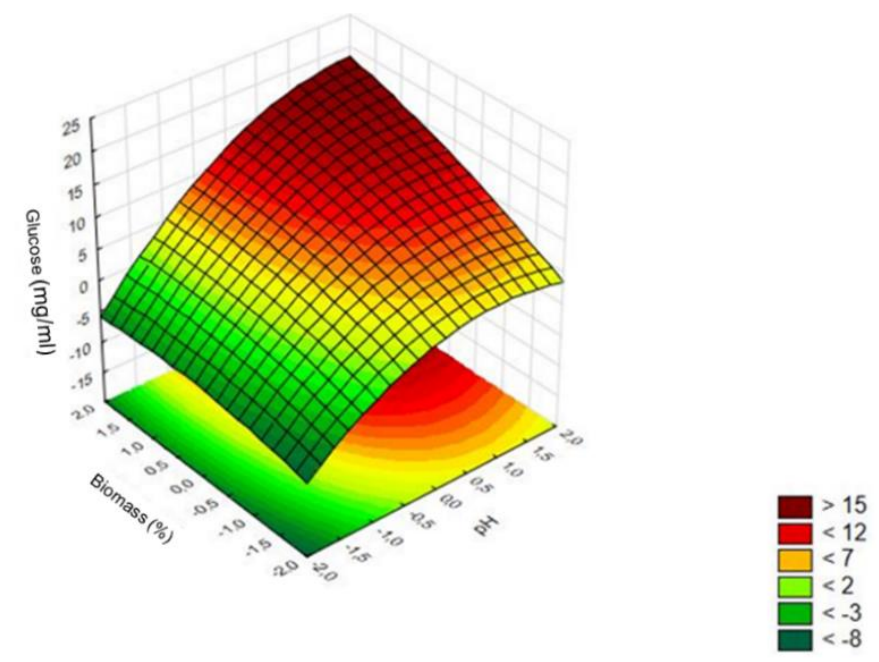

Figure 4: Response surface graph of the influence of $\mathrm{pH}$ and biomass on glucose release using pretreated biomass. Values according to the design.

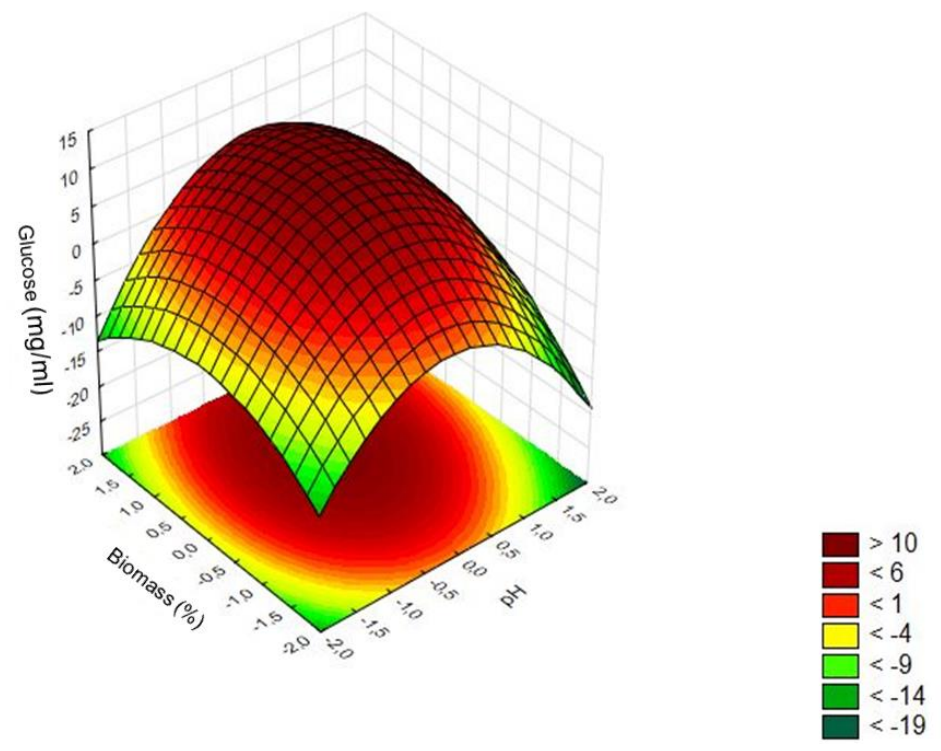

Figure 5: Response surface graph of the influence of $p H$ and biomass on glucose release using biomass without pretreatment. Values according to the design. 
From the response surface graph, it can be concluded that for the PT biomass, the best value of released glucose concentration is reached with the increase in $\mathrm{pH}$ to the central point; the biomass concentration had a progressive effect between the minimum and maximum points.

For biomass ST, the quadratic effect of $\mathrm{pH}$ was high in relation to the other variables, thus forming a parabola, indicating that an intermediate $\mathrm{pH}$ is ideal for hydrolysis, noting that biomass (\%) also had a parabolic effect, but not as expressive as the $\mathrm{pH}$.

\section{CONCLUSION}

Pineapple crown proved to be a good source of carbon for the growth of $F$. oxysporum and for the production of cellulolytic and xylanolytic enzymes, mainly xylanase.

The pre-treatment, with an average yield of almost 30\%, favored the saccharification of cellulose into glucose, when compared to the hydrolysis of biomass without treatment.

Statistical planning was efficient in determining the effect and response of variables $(\mathrm{pH}$, biomass concentration and incubation time) in relation to glucose release, since $\mathrm{pH}$ is the main factor that has an effect on this process.

\section{REFERENCES}

1. Saini JK, Saini R, Tewari L. Lignocellulosic agriculture wastes as biomass feedstocks for secondgeneration bioethanol production: concepts and recent developments. 3 Biotech. 2015 Aug;5(4):33753. doi: 10.1007/s13205-014-0246-5

2. Leite P, Silva C, Salgado JM, Belo I. Simultaneous production of lignocellulolytic enzymes and extraction of antioxidant compounds by solid state fermentation of agro-industrial residues. Ind Crops Prod. 2019 Oct;137:315-22. doi: 10.1016/j.indcrop.2019.04.044

3. Toushik SH, Lee KT, Lee JS, Kim KS. Functional applications of lignocellulolytic enzymes in the fruit and vegetable processing industries. J Food Sci. 2017 Feb;82(3):585-93. doi: 10.1111/1750-3841.13636

4. Conesa C, Seguí L, Laguarda-Miró N, Fito P. Microwave as a pre-treatment to enhance the enzymatic hydrolysis of industrial pineapple residues for bioethanol production. Food Bioprod Proc. 2016 Oct;100(Part A):203-13. doi: 10.1016/j.fbp.2016.07.001

5. Roda A, De Faveri DM, Giacosa S, Dordoni R, Lambri M. Effect of pre-treatments on the saccharification of pineapple waste as a potential source for vinegar production. J Clean Prod. 2016 Jan;112(5):4477-84. doi: 10.1016/j.jclepro.2015.07.019

6. Saini JK, Patel AK, Adsul M, Singhania RR. Cellulase adsorption on lignin: a roadblock for economic hydrolysis of biomass. Renew Energ. 2016 Dec;98:29-42. doi: 10.1016/j.renene.2016.03.089

7. Nadar SS, Rao P, Rathod VK. Enzyme-assisted biomolecule extraction as an approach to a new extraction technology: a review. Food Res Int. 2018 Jun;108:309-30. doi: 10.1016/j.foodres.2018.03.006

8. Radenkovs V, Górnaś KJRP, Seglina D. Non-waste technology through enzymatic hydrolysis of agroindustrial by-products. Trends Food Sci Technol. 2018 Jul;77:64-76. doi: 10.1016/j.tifs.2018.05.013

9. De Paula RG, Antoniêto ACC, Nogueira KMV, Ribeiro LFC, Rocha MC, Malavazi I, et al. Extracellular vesicles carry cellulases in the industrial fungus Trichoderma reesei. Biotechnol Biofuels. 2019 Jun;12(1):1-14. doi: 10.1186/s13068-019-1487-7

10. Yuan L, Wang W, Pei Y, Lu F. Screening and identification of cellulase-producing strain of Fusarium oxysporum. Procedia Environ Sci. 2012;12(Part B):1213-9. doi: 10.1016/j.proenv.2012.01.410

11. Panagiotou G, Topakas E, Moukouli M, Christakopoulos P, Olsson L. Study of the ability of Fusarium oxysporum and Saccharomyces cerevisiae recombinant to cooperate efficiently in the decomposition and ethanolic fermentation of wheat straw. Biomass Bioenergy. 2011 May;35(8):3727-32. doi: 10.1016/j.biombioe.2011.05.005

12. Panagiotou G, Christakopoulos P, Olsson L. Simultaneous saccharification and fermentation of cellulose by Fusarium oxysporum F3 - growth characteristics and metabolite profiling. Enzyme Microb Technol. 2005 Apr;36(5-6):693-9. doi: 10.1016/j.enzmictec.2004.12.029

13. De Araújo WL, Lima AOS, De Azevedo JL, Marcon J, Sobral JK, Lacava PT. Manual: isolamento de microrganismos endofíticos. Piracicaba (SP): CALQ; 2002.

14. Figueiredo MB. Aplicação do método de Castellani para conservação de fungos fitopatogênicos. Fitopatol Bras. 1967;(1):79-81. 
15. Miller GL. Use of dinitrosalicylic acid reagent for determination of reducing sugar. Anal Chem. 1959;31(3):426-28. doi: 10.1021/ac60147a030

16. LABTEST. Glicose Liquiform - Instruções de Uso. [Lagoa Santa (MG)]: Labtest Diagnóstica S.A; 2011.

17. Roda A, De Faveri DM, Giacosa S, Dordoni R, Lambri, M. Effect of pre-treatments on the saccharification of pineapple waste as a potential source for vinegar production. J Clean Prod. 2016 Jan;112(Part 5):4477-84. doi: 10.1016/j.jclepro.2015.07.019

18. Santos FA, De Carvalho-Gonçalves LCT, Cardoso-Simões ALC, Santos SFM. Evaluation of the production of cellulases by Penicillium sp. FSDE15 using corncob and wheat bran as substrates. Bioresour Technol Rep. 2021 Jun;14:100648. doi: 10.1016/j.biteb.2021.100648

19. Kumar V, Chhabra D, Shukla P. Xylanase production from Thermomyces lanuginosus VAPS-24 using low cost agro-industrial residues through hybrid optimization tools and its potential use for saccharification. Bioresour Technol. 2017 Jul;243:1009-19. doi: 10.1016/j.bioetech.2017.07.094

20. Xu J, Wang X, Liu X, Xia J, Zhang T, Xiong P. In situ enzymatic saccharification of lignocellulosic biomass in ionic liquids using ionic liquid tolerant cellulases. Biomass Bioenergy. 2016 Oct;93:180-6. doi: 10.1016/j.biombioe.2016.07.019

21. Maitan-Alfenas GP, Oliveira MB, Nagem RA, De Vries RP, Guimarães VM. Characterization and biotechnological application of recombinant xylanases from Aspergillus nidulans. Int J Biol Macromol. 2016 Oct;91:60-7. doi: 10.1016/j.ijbiomac.2016.05.065

22. Singh A, Bajar S, Devi A, Bishnoi N. Radding value to agro-industrial waste for cellulase and xylanase production via solid-state bioconversion. Biomass Convers Biorefin. 2021. doi: 10.1007/s13399-02101503-z

23. Raghuwanshi S, Deswal D, Karp M, Kuhad RC. Bioprocessing of enhanced cellulase production from a mutant of Trichoderma asperellum RCK2011 and its application in hydrolysis of cellulose. Fuel. 2014 Feb;124:183-9. doi: 10.1016/j.fuel.2014.01.107

24. Sun Y, Cheng J. Hydrolysis of lignocellulosic materials for ethanol production: a review. Bioresour Technol. 2002 Oct;83(1):1-11. doi: 10.1016/S0960-8524(01)00212-7

25. Granato D, Calado VMA, Jarvis B. Observation on the use of statistical methods in Food Science and Technology. Food Res. Int. 2014 Oct;55:137-49. doi: 1016/j.foodres.2013.10.024

26. Scheufele FB, De Siqueira BA, Marra IF, Hasan SDM, Fiorese ML. Otimização dos parâmetros de hidrólise enzimática do bagaço de cana-de-açúcar. Engevista. 2012 Dec;14(3):310-21. doi: 10.22409/engevista.v14i3.421 